\title{
Ewolucja dyskursu o partycypacji społecznej dzieci
}

\author{
EWA JAROSZ1 \\ 1 Uniwersytet Śląski w Katowicach, ul. Grażyńskiego 53, 40-126 Katowice. ORCID: \\ 0000-0002-3207-0148, Email: ewa.jarosz@us.edu.pl
}

STRESZCZENIE: Koncepcja partycypacji społecznej dzieci jest w dzisiejszym świecie rozumiana jako wielowymiarowa, wielopostaciowa, a także konieczna do wdrażania na różnych poziomach społecznych. Od chwili jej wyrazistego sformułowania w Konwencji o prawach dziecka z 1989 roku, rozwój naukowego i praktycznego dyskursu na temat partycypacji dzieci charakteryzuje swoista ewolucja, której cechą jest zmiana istoty rozumienia znaczenia partycypacji dzieci z narzędzia rozwoju podmiotowości dziecka oraz rozwoju demokracji w społeczeństwie - jak było to we wcześniejszych dekadach - na postrzeganie jej jako wartości samej w sobie oraz pożądanej cechy charakteryzującej życie społeczne. Obecnie oznacza ona również akcentowanie zbiorowego wymiaru partycypacji dzieci oraz przesunięcie teoretycznego kontekstu idei w obszar teorii społeczno-politycznych. Artykuł przedstawia szkic charakterystyki owej ewolucji.

SŁOWA KLUCZE: partycypacja dzieci, obywatelstwo dzieci, prawa dziecka, demokracja

\section{WPROWADZENIE}

Od kilku dekad w badaniach i naukowym dyskursie dotyczącym dzieci oraz młodzieży rozwija się perspektywa dziecka, która odwołuje się do innej niż wcześniej podstawy rozumienia wzajemnej relacji między dzieckiem a dorosłym, uwzględniając transfor- 
mację stosunków pomiędzy nimi. Postawa protekcji wobec dzieci ustępuje uznaniu ich społecznego uczestnictwa (w tym jego rozwijaniu), aktywnego obywatelstwa oraz partnerstwa we wzajemnych stosunkach. Dzieci zaczynają być intensywniej włączane w decyzje i działania społeczne na różnych poziomach (Lansdowne 2010). Dawna postawa „dla dzieci” zastąpiona zostaje postawą „z dziećmi”, co zdaje się pokrótce oddawać sens tego, czym jest partycypacja społeczna dzieci. Jej istotą jest bowiem idea współdziałania, współorganizowania rzeczywistości oraz partnerskie rozwiązywanie różnego rodzaju problemów dotyczących dzieci i ich środowiska. Relacja między światem dorosłych i światem dzieci widziana oraz postulowana jest w kategoriach równości, wzajemnego szacunku i równouprawnienia.

Podstawowa promocja koncepcji partycypacji dzieci została zawarta w Konwencji o prawach dziecka z 1989 roku, dokumencie ratyfikowanym przez wszystkie (z jednym wyjątkiem) kraje, który wyznacza standardy warunków życia i rozwoju dzieci. Art. 12. określa prawa partycypacyjne dzieci, to jest prawo do swobodnego wyrażania własnych poglądów oraz obowiązek przyjmowania ich z należytą powagą, stosownie do zdolności dziecka. Kolejne artykuły (13., 14., 15., 16. i 17.) ideę partycypacji społecznej dzieci wyrażają jako prawo do: swobodnej wypowiedzi, (odpowiedniej) informacji, swobody myślenia, sumienia i wyznania, swobodnego zrzeszania się, prywatności oraz dostępu do informacji medialnych. Specjaliści tematu podkreślają, że poprzez owe artykuły w Konwencji zaakcentowano nie tylko prawo dzieci do samostanowienia i bycia wysłuchanymi ale jednocześnie określono ich status jako pełnoprawnych obywateli (Wyness 2012).

Studia nad dyskursem o partycypacji dzieci i młodzieży wskazują, że jej przestrzeń i wymiary w życiu społecznym mają wieloraki i wielopostaciowy charakter w perspektywie globalnej. Dyskurs ten nie jest bowiem jednorodny, monolityczny, przypomina raczej mozaikę tworzącą barwny, z wieloma odcieniami, obraz. W licznych opracowaniach zauważyć można ogromne zróżnicowanie rozumienia tego, czym jest partycypacja. Zróżnicowanie to ma miejsce w zależności od warunków społeczno-kulturowych i politycznych, na gruncie których jest ona rozpatrywana (Liebel 2017, Percy-Smith 2010). Co więcej, sam termin „partycypacja” w niektórych kulturach nie posiada swojego odpowiednika, zaś zjawiska, które nazywane są w języku świata zachodniej demokracji partycypacją, opisywane są za pośrednictwem zupełnie innych terminów. Słusznie więc Manfred Liebel wskazuje, że najtrafniejszym nastawieniem wobec tematu i rozważań o partycypacji jest podejście międzykulturowe, bowiem wymaga ono powstrzymywania się od prostych klasyfikacji oraz ocen na temat różnych koncepcji czy praktyk partycypacji dzieci. Autor proponuje tym samym odejście od stosowania jednakowych kryteriów oraz binarnego wartościowania przejawów partycypacji, które bazuje na opozycji między tym, co lepsze lub gorsze, bardziej postępowe lub bardziej zacofane (Liebel 2017). Podobne stanowisko prezentuje Michel Wyness (2018) podkreślający, że partycypacja jest złożonym tematem, to jest dynamicznie dyskutowanym, pozbawionym jednoznacznych i podzielanych powszechnie definicji, które ujmowałyby bogactwo wszystkich form partycypacji dzieci. Wskazuje on jednak, że mimo możliwości mówienia o pewnym podstawowym uniwersum partycypacja przybiera w rzeczywistości różne formy, a także realizowana jest poprzez odmienne praktyki (Wyness 
2018: 105).

W ostatnich latach zauważyć można dynamiczny wzrost liczby badań, opracowań i raportów na temat partycypacji społecznej dzieci. Znacząco też rozszerza się zakres problematyki badań podejmujących coraz bardziej zróżnicowane jej aspekty. Jednocześnie śledząc przedmiotowy dyskurs z perspektywy historycznej, dostrzec można istotną zmianę kontekstu teoretycznego partycypacji, stylu narracji wykorzystywanej do jej opisu, w końcu także zjawisk związanych z jej implementacją w praktyce społecznej. Wydaje się więc, że w ciągu kilku dekad mamy do czynienia ze znaczącą ewolucją dyskursu o partycypacji.

W niniejszym tekście podejmę próbę szkicowego określenia kilku aspektów zmiany dyskursu o partycypacji dzieci - z uwzględnieniem jej wspomnianej wielopostaciowości oraz podejścia wielokulturowego, któremu patronuje Liebel. W tym celu zamierzam odnieść się do wyróżnionych przeze mnie wyżej autorów oraz przedmiotowych problemów ewolucji koncepcji partycypacji.

\section{PARTYCYPACJA INDYWIDUALNA, PARTYCYPACJA JAKO NARZĘDZIE - DYSKURS WYGASAJĄCY}

W pierwszych dekadach rozwoju dyskursu o partycypacji dzieci podstawowym kontekstem ideowo-teoretycznym były wspomniane koncepcje tzw. nowej socjologii dziecka, w ramach których występuje ono jako aktor społeczny, aktywny uczestnik życia społecznego. Dziecko zostało wówczas okrzyknięte konstruktorem swojego świata, ale także współkonstruktorem świata społecznego jako takiego. Nowa socjologia dziecka promowała jego wartość i pozycję w układzie społecznym i zmieniła rozumienie z przedmiotu działań wychowawczych i socjalizacyjnych w podmiot społeczny i kulturowy (Prout i James 1997, Corsaro 2015, Jenks 2008).

Badacze nowej socjologii dziecka zostali wsparci przez przedstawicieli niektórych nurtów pedagogiki, zwłaszcza emancypacyjnej i antyautorytarnej, które podkreślały zdolności i kompetencje dziecka do decydowania i działania społecznego, w końcu do zarządzania własnym rozwojem oraz kreowania swojej rzeczywistości. Akcentowały także potrzebę rozwijania podmiotowości dziecka i wspierania go w tworzeniu, autonomii i wolności tworzenia własnego życia (zob. Śliwerski 2003, Śliwerski 2007).

Adwokaci „nowego dziecka” i nowej pedagogiki zdefiniowali nowy status dziecka, funkcjonujący w przestrzeni równości z dorosłymi. W efekcie zaczął rozwijać się dyskurs o dziecku będącym równoważnym partnerem w relacji z dorosłym, przy czym ta zasadza się na wymianie pomiędzy równie ważnymi stronami, z nieokreśloną jednoznacznie pozycją autorytetu (Szczepska-Pustkowska 2011). Ponadto autorzy owych nurtów podkreślali konieczność uznania wartości społecznej świata tworzonego przez dziecko, a także wskazywali na potrzebę dokonania rekonstrukcji obrazu dzieciństwa, jego redefinicji wraz z kulturą dzieciństwa. W tym celu postulowano, by na dzieciństwo spoglądać oczami samych dzieci. Apelowano zatem o badanie dzieciństwa poprzez analizę stosunku dziecka do sobie i swojego świata (Jenks 2008).

Powyższe stanowiska teoretyczne podkreślały znaczenie partycypacji dzieci głównie w wymiarze korzyści dla rozwoju ich podmiotowości oraz wskazywały na inne ko- 
rzyści rozwojowe, jakie dzieci odnoszą poprzez partycypację - zwłaszcza korzyści psychologiczne i socjalizacyjne. Podkreślały również pozytywne skutki partycypacji dzieci dla otoczenia, a wręcz całego społeczeństwa. Wskazywano na rozwój odpowiedzialności dziecięcej, postaw społecznych oraz kompetencji obywatelskich, ale także na profity społeczne płynące z energii i pomysłowości młodych ludzi. Można powiedzieć, że w tym ujęciu przeważało rozumienie partycypacji jako procesu a nawet narzędzia prowadzącego do osiągania: a) korzyści indywidualnych, to jest mocniej rozwijającej się podmiotowości oraz rozwoju kompetencji społecznych u dzieci; b) korzyści społecznych, np. dojrzalszego społeczeństwa obywatelskiego czy zysków dla otoczenia wynikających z pomysłowości młodych. Jak można zauważyć, partycypacja dzieci w tym ujęciu była ujmowana jako metoda, droga prowadząca do osiągania różnych wartości indywidualnych i społecznych (Thomas 2012, Wyness 2018). Argumentem za jej upowszechnianiem były zarówno jednostkowe korzyści rozwojowe, jak i te mogące pozytywnie oddziaływać na całe społeczeństwo.

\section{PARTYCYPACJA ZBIOROWA, PARTYCYPACJA JAKO WARTOŚĆ - DYSKURS ZACZYNAJĄCY DOMINOWAĆ}

Od stosunkowo długiego czasu rozwijał się dyskurs o sytuacji dzieci jako osób dyskryminowanych i grupy dyskryminowanej społecznie. Tak na przykład już w 1900 roku Charlotta Perkins Gillman, autorka słynnego feministycznego manifestu „Herland”, w innej swojej pracy pt. „Concerning children” wskazywała na dyskryminację dzieci jako grupy społecznej, nazywając je, w tym sensie, grupą mniejszościową. Pisała bowiem:

Rozważając sytuację dzieci musimy pamiętać, że stoi przed nami permanentna grupa społeczna, czasami większa niż populacja dorosłych. Ale jako członkowie społeczeństwa nie otrzymują one niemal żadnej uwagi i nie są rozpoznawane jako należące do społeczeństwa (Rosen i Twamley 2018).

W tym duchu nawoływania do uznania dzieci i ich równości społecznej jako grupy pojawia się też postać Janusza Korczaka, który zwracał uwagę na powszechne zjawisko dyskryminowania dziecka, w tym przez dorosłych. Korczak zabiegał o uznanie dziecka jako obywatela, członka wspólnoty uprawnionego do decydowania i uczestnictwa w życiu społecznym, a nawet do samozarządzania: „Dziecko - już mieszkaniec, obywatel i już człowiek. Nie dopiero będzie, a już [...]”, pisał (Korczak 1928). Wiele lat później, to jest w latach 70-tych, w spektakularny sposób sytuację dzieci w kategoriach społecznego wykluczenia zdefiniował John Holt (1974), który pisał: „[...] dzieci pozostają nadal ostatnią z rozległych grup społecznych, którą powszechnie dotyka społeczna dyskryminacja”.

Antydyskryminacyjna tonacja dyskursu przebijała się coraz wyraźniej wraz z postępującą demokratyzacją życia oraz walką o demokrację w różnych państwach w Europie, obu Amerykach i Australii, wywołując dyskusje o dostęp dzieci do zasobów, usług i dóbr społecznych, jak i do procesów oraz decyzji społecznych (zob. np. Freire: 2005). W dyskursie naukowym, ale też i politycznym, zaczął być malowany obraz dzieci jako pełnoprawnej grupy społecznej, uczestników wspólnoty, członków społeczności szkol- 
nej, środowiskowej, społecznej, państwowej czy regionalnej (Lister 2009). Ten wymiar dyskursu jest silnie oparty na rozumieniu partycypacji w wymiarze zbiorowym, to jest rozumienia dzieci jako grupy społecznej. Zdaje się być on akcentowany, a wręcz dominujący, we współczesnym dyskursie. Jest swoistą oznaką omawianej tu ewolucji.

Podstawy zbiorowego wymiaru rozumienia partycypacji dzieci wskazano w Komentarzu Ogólnym Komitetu Praw Dziecka nr. 12. „The right of the child to be heard /CRC/C/GC/12” z 2009 roku (zob. „Prawa dziecka” 2015), w którym wyjaśniono, że państwa powinny zachęcać dzieci do formułowania i wyrażania swoich poglądów oraz powinny stwarzać ku temu rzeczywiste warunki i możliwości (Lundy 2007). Jeszcze wcześniej, w Komentarzu nr 5. Komitetu Praw Dziecka „O wprowadzaniu w życie Konwencji o prawach dziecka” z 2003 roku, wskazano na konieczność rozwijania bezpośrednich relacji rządów państw z szerokimi grupami dzieci w celu ustalania ich poglądów oraz kreowania odpowiedniej polityki w różnych sektorach. W dokumencie tym podkreślono przy tym, że chodzi o bezpośrednie relacje z dziećmi, niezapośredniczone przez „media”, jak na przykład organizacje pozarządowe wypowiadające się w imieniu dzieci. Jak można zauważyć, wyraźnie wskazano tu potrzebę realizacji praw partycypacyjnych dzieci nie tylko w kontekście indywidualnym ale też, a raczej przede wszystkim, w znaczeniu zbiorowym jako grup i populacji. Tak zresztą odczytywane jest owo stanowisko Komitetu przez wielu czołowych przedstawicieli dyskursu o partycypacji dzieci, w tym Manfreda Liebela (2017), Nigela Thomasa (2007) czy Larę Lundy (2007 i 2018).

Wiele dokumentów oraz wielu autorów uwzględnia zbiorowy wymiar partycypacji dzieci oraz doprecyzowuje jego przejawy i formy. Poza udziałem dzieci jako grupy społecznej w decydowaniu i projektowaniu działań czy w opracowywaniu rozwiązań dotyczących spraw bezpośrednio lub pośrednio odnoszących się do dzieci i młodzieży oraz ich problemów - a na wyższym stopniu rozwoju partycypacji spraw współzarządzania rzeczywistością lub jej określonymi częściami - wymienia się w tym względzie udział dzieci w ocenie działań i rozwiązań, które podejmowane są na ich rzecz, a także prawo krytykowania tych działań. Wymieniane są takie kwestie, jak dostęp dzieci i młodzieży jako grupy społecznej do odpowiednio przygotowanej informacji dotyczącej spraw i problemów, a także decyzji i rozwiązań, jakie w kwestiach dzieci są podejmowane. Innym aspektem realizowania partycypacji w zbiorowym sensie jest przejawianie przez dzieci i młodzież swojej opinii w sprawach własnych i środowiska, w którym żyją oraz na temat decyzji politycznych, jakie są podejmowane, przy zachowaniu prawa do swobodnej ekspresji owych poglądów. Kolejnym wymiarem partycypacji dzieci w wymiarze zbiorowym jest możliwość tworzenia własnej relacji o rzeczywistości poprzez tworzenie informacji, prowadzenie serwisów, stron informacyjnych, tworzenie tekstów, twórczość artystyczną czy też inne media i komunikatory. Następną formą urzeczywistniania się partycypacji zbiorowej jest tworzenie się różnych form dziecięcej i młodzieżowej wspólnotowości oraz zrzeszanie się młodych ludzi w stowarzyszania, ruchach i organizacjach oraz innych formach samoorganizowania się inspirowanych oraz zarządzanych całkowicie przez dzieci i młodzież lub przy wsparciu dorosłych. Inną postacią partycypacji jest społeczna działalność dzieci dla innych dzieci czy dorosłych, działalność na rzecz wspólnego dobra, na rzecz środo- 
wiska społecznego czy - ostatnio widoczne coraz intensywniej - działania grup dzieci i młodzieży na rzecz środowiska naturalnego. Z pewnością też wymiaru grupowego rozumienia partycypacji dzieci dotyczy współudział dzieci i młodzieży w badaniu problemów i sytuacji, które ich dotyczą, badań różnych wymiarów życia i jego jakości przy wsparciu dorosłych lub we współpracy z nimi.

Wszystkie te przejawy i formy są ukazywane jako wartości w perspektywie cech stanu społecznego, jaki powinien charakteryzować społeczeństwo i jego podstruktury.

\section{TEORETYCZNE PODSTAWY ROZWOJU DYSKURSU O PARTYCYPACJI DZIECI JAKO WARTOŚCI}

Zmiana perspektywy rozważań dotyczących partycypacji dzieci z profilu indywidualnego i postrzegania znaczenia partycypacji jako narzędzia wymagała sięgnięcia po inne zaplecze teoretyczno-ideowe niż idea „nowego dziecka”, które może i jest aktorem społecznym oraz którego podmiotowość jest uznana, ale też powinna być rozwijana poprzez partycypację. Nigel Thomas (2012) zauważa, że we współczesnym dyskursie coraz bardziej rozwijają się próby użytkowania szerszych ujęć teoretycznych. Jego zdaniem podłożem jest tu sama koncepcja praw człowieka i praw dziecka, idee demokracji oraz pedagogiczne idee wyzwolenia i emancypacji dziecka. Wskazywanym przez niego przykładem jest pedagogika Paulo Friere. Thomas zauważa, że badacze kontestując teoretycznie dyskurs o partycypacji dzieci, coraz częściej sięgają do teorii społecznych i politycznych. Tłem rozważań stają się teorie demokracji liberalnej zaproponowane przez Toma Cockburna (2010 i 2013) - albo teorie rządzenia i zarzadzania, reprezentowane chociażby przez Therese O’Toole i Richarda Gale'a (2008) czy Kay Tisdall (2010). Z kolei Greg Mannion (2004 i 2010) wykorzystał teorię przestrzeni, zaś Ann Graham i Robyn Fitzgerald (2010) zaproponowały teorie dialogu społecznego i inkluzji (2010). W dyskursie o partycypacji dzieci wykorzystywane są także teorie zmiany społecznej oraz ogólne teorie obywatelstwa i partycypacji społecznej (Thomas: 2012). Dla kształtowania się dyskursu o partycypacji dzieci istotne stają się też koncepcje metodologiczne, takie jak participatory action research, którą w narracji o partycypacji dzieci inspiruje się Barry Percy-Smith (2010 i 1998).

Zdaniem Thomasa (2010, 2012), inspirującym kontekstem teoretycznym aktualnego dyskursu o partycypacji dzieci są koncepcje polityczne. W ich ramach Thomas przedstawia koncepcje Marion Young oraz Pierre'a Bourdieu, a także odwołania do innych ogólniejszych stanowisk teoretycznych z kręgu koncepcji „walki o uznanie”, jak na przykład koncepcje Charlesa Taylora czy Nancy Fraser (Fitzgerald i in. 2010, Thomas 2010 i 2012). Jednak za szczególnie przydatną uważa on teorię uznania zaproponowaną przez Axela Honneth'a (2012).

Jak więc można zauważyć w podpowiedziach Nigela Thomasa, obecny dyskurs o partycypacji dzieci dryfuje w stronę teorii społeczno-politycznych, które stawiają w aksjologicznym centrum urzeczywistnianie głębokiej demokracji, aktywnego obywatelstwa wszystkich grup społecznych oraz partycypacji społecznej równoprawnej dla wszystkich, w tym dla dzieci. Partycypacja dzieci jest więc tu wartością, celem, jaki powinien zostać osiągnięty. W tym duchu orędujący za partycypacją dzieci mówią o ich 
równości w dostępie do wszelakich zasobów oraz procesów decydowania i zarządzania, o równości w dostępie do praw oraz do społecznego i kulturowego działania jak i tworzenia. Oznacza to, że demokracja jako taka, urzeczywistnianie jej sensu i fundamentalnych zasad, dokonuje się poprzez niwelowanie nierówności i dyskryminacji, dzięki szerokiej inkluzji społecznej dzieci, co stanowi zasadniczy argument na rzecz implementowania i zapewniania dzieciom partycypacji społecznej. Manfred Liebel (2017) podkreśla, że to wyraźny zwrot w dyskursie, gdyż wcześniej kwestie dyskryminacji społecznej ze względu na wiek były słabo eksponowane - nie były widoczne ani w debatach o prawach człowieka, ani nawet w samej Konwencji o prawach dziecka. Jego zdaniem powodem tej zmiany jest to, że współczesna rzeczywistość i różnego rodzaju zjawiska spowodowały rozmycie granic pomiędzy dorosłością a dzieciństwem, granic w tradycyjnych kryteriach ich rozróżniania. Liebel (2017) zauważa bowiem, że obecnie wyraźny podział pomiędzy dziećmi a dorosłymi przestaje być uzasadniony. Jest to szczególnie widoczne w odniesieniu do takich obszarów, jak: odpowiedzialność, obowiązki, nauka, praca, kompetencje i umiejętności użytkowania dóbr, zwłaszcza nowych technologii. Współcześnie nawet rozróżnienie dzieci i dorosłych pod względem dojrzałości społeczno-kulturowej zdaje się zacierać, przez co podział ten nie jest już tak kategoryczny. Zdaniem Liebela (2017) owo zatarcie granic wzmacnia się i rozwija w dyskursie o partycypacji dzieci jako należnej im w prawach i z mocy idei równości, a także wewnątrz demokracji i społeczeństwa obywatelskiego.

Coraz częstsze użytkowanie teorii społecznych i politycznych w obecnym dyskursie o partycypacji dzieci powoduje, że uwydatniane są w nim takie terminy, jak: inkluzja, partnerstwo, współdziałanie, współzarządzanie, dialog społeczny, społeczne uznanie. Dzisiaj to właśnie te pojęcia zaczynają dominować nad wcześniejszą narracją o partycypacji, w której pojawiały się odwołania do dziecka jako aktora społecznego, jego podmiotowości i zdolności do wyrażania opinii oraz podejmowania decyzji. Niemniej dawne konteksty teoretyczne i związana z nimi terminologia są wciąż aktualne. Partycypacja dzieci nadal postrzegana jest jako droga do ich indywidualnego rozwoju, czynnik wzmacniania osobistego dobrostanu, wspieranie rozwoju podmiotowości, edukacja postaw obywatelskich i sposób rozwoju aktywnego obywatelstwa oraz społeczeństwa obywatelskiego. Zmiana, która następuje, polega na przesunięciu akcentu z teoretyczno-ideowego podłoża argumentacji na rzecz urzeczywistniania partycypacji dzieci. Obecność i silniejszy wydźwięk teorii społeczno-politycznych, wraz z ich pojęciami i kategoriami, w aktualnych dyskusjach o partycypacji oznacza więc przede wszystkim zmianę preferencji co do rodzaju argumentów, nie zaś całkowity odwrót od wcześniejszych podejść.

\section{PODSUMOWANIE - CO WYNIKA Z EWOLUCJI DYSKURSU O PARTYCYPACJI DZIECI?}

Koncepcja partycypacji dzieci jest rozumiana zarówno w sensie indywidualnym jak i zbiorowym. Przegląd aktualnego dyskursu o partycypacji dzieci dowodzi, iż zbiorowe, kolektywne rozumienie partycypacji dzieci przeważa pod względem ilościowym, jest preferowane w badaniach i opracowaniach. Nie dziwi to w kontekście dotychczasowe- 
go rozwoju ogólnego „ducha” demokracji i nawoływań do poszanowania praw różnych grup i zbiorowości, a także ogólnego rozwoju koncepcji i tendencji emancypacyjnych. Przyjęcie perspektywy zbiorowej jako podstawowego kontekstu w rozważaniach nad partycypacją dzieci akcentuje, że jest ona prawem nie tylko poszczególnych dzieci, ale nade wszystko grup i zbiorowości dzieci - od najmniejszych (klasa szkolna czy grupa dzieci w jakiejś instytucji), poprzez większe (dzieci żyjące w danym środowisku lokalnym czy w ramach grupy wyznaniowej lub etnicznej), do największych (populacje dzieci w społeczeństwie i państwie). Taka perspektywa ma swoje polityczne i praktyczne konsekwencje. Oznacza bowiem wskazanie państwom i innym podmiotom zarządzającym w środowiskach lokalnych, instytucjach czy organizacjach, że dzieci powinny być przez nie traktowane jako grupa społeczna czy zbiorowość z możliwie szerokim, demokratycznym udziałem, jako grupa o realnym wpływie na decyzje podejmowane w kwestiach, które mogą dotyczyć dzieci w bieżącej sytuacji a także w przyszłości (Thomas 2010). W praktyce oznacza również uznanie dzieci za rozległą grupę społeczną, której opinie muszą być wysłuchane i uwzględniane w polityce instytucji, polityce lokalnej oraz państwowej w kwestii procesów decydowania o sprawach istotnych dla nich aktualnie i w przyszłości (Taylor i Percy-Smith: 2008). Co więcej, oznacza to uznanie, że dzieci są grupą społeczną kreującą życie społeczno-kulturalne, co wymusza także uwzględnienie konsekwencji przyjmowanego w ten sposób stanowiska.

Powyższe założenia mają swoje konsekwencje w praktyce społecznego funkcjonowania społeczeństw i środowisk. Chodzi o respektowanie zasad: dążenia do pozyskania poglądów dzieci wypowiadających się zbiorowo, konsultowania decyzji z szerokimi środowiskami i grupami dzieci, uzyskiwania ich opinii czy ocen, ale też współpracy z grupami dzieci nad wypracowywaniem rozwiązań lub programów i ich realizacji, co podkreśla Manfred Liebel(2017).

Partycypacja dzieci rozumiana jako wartość w wymiarze zbiorowym oznacza także, że w podejmowanych w polityce wieloobszarowych ustaleniach - które dotyczą realnie bądź potencjalnie dzieci (i ich przyszłości) - kategorią krytyczną dla podejmowanych rozstrzygnięć jest najlepszy interes dzieci, ich dobro i dobrostan. Niezbędne okazuje się zatem stworzenie takich przestrzeni i mechanizmów przez osoby zarządzające instytucjami, urzędami, organami samorządowymi czy państwowymi, aby w obszarze polityki i działań uwzględniających dobro dzieci pojawiła się wystarczająca szansa na ich udział w podejmowanych decyzjach i rozwiązaniach. Co więcej, powinna zostać im zagwarantowana możliwość monitorowania realizowanych na ich rzecz polityk i programów. Rozumienie partycypacji w kategoriach społeczno-politycznych praw dzieci jako grupy i zbiorowości oznacza również uznanie ważności treści i formy wypowiedzi dzieci oraz niedyskryminowanie ich pod względem poglądów czy środków ich prezentowania, nawet jeśli przyjmuje to postać kłopotliwą lub trudną dla dorosłych (Hayward 2012). Kolejnym wymiarem tak rozumianej partycypacji jest poszanowanie prawa dzieci do informacji - zakaz ograniczania młodym ludziom dostępu do tych, które w bezpośredni sposób odnoszą się do ich aktualnej lub przyszłej sytuacji. Oznacza to zatem obowiązek zapewnienia informacji, które przekazywane są w sposób przyjazny dzieciom, dostęp do przestrzeni i środków tworzenia informacji oraz umożliwianie 
dzieciom wytwarzania i upowszechniania wiedzy na temat własnego stosunku do rzeczywistości i wszystkiego, co uznają one ważne dla siebie i swojego świata. Obszarem partycypacji wyróżniającym się w kontekście jej zbiorowego rozumienia jest również dostęp młodych ludzi do dóbr i praw życia politycznego, a więc możliwość stowarzyszania się, tworzenia własnych, zarządzanych przez nich lub we współpracy z dorosłymi, organizacji (Johnson 2009), w końcu jest to również stwarzanie młodym możliwości tworzenia ruchów społecznych. Należy również podkreślić, że w kontekście zbiorowego rozumienia partycypacji dzieci pojawia się także konieczność włączania młodych ludzi w dyskurs o ich partycypacji społecznej. Realizując ideę dialogu społecznego z dziećmi należy więc badać, eksplorować i omawiać partycypację wspólnie, co prowadzić ma do rozważania z ich udziałem problemów i działań służących jej urzeczywistnianiu i włączaniu w rozmaite konteksty społeczne. W imię partycypacji i inkluzji niezbędna okazuje się zatem zmiana sposobu uprawiania samego dyskursu o partycypacji młodych, skupiająca się wokół odejścia od dotychczasowego, monologicznego jej uprawiania przez dorosłych na rzecz podejścia dialogicznego, z dziećmi.

\section{BIBLIOGRAFIA}

Cockburn, Tom. 2010. Children and deliberative democracy. W: B. Percy-Smith, N. Thomas (red.), A Handbook of Children and Young People's Participation. Perspectives From Theory and Practice. London and New York: OXON, Routledge.

Cockburn, Tom. 2013. Rethinking children's citizenship. New York: Palgrave Macmillan. Corsaro, William. 2015. The Sociology of Childhood. Los Angeles: SAGE.

Dahl, Tove. 2014. Children as Researchers: We Have a Lot to Learn. W: G. Melton i in. (red.), The SAGE Handbook of Child Research. Los Angeles-Washington: SAGE.

Fitzgerald, Robyn i Graham, Anna i Smith, Ann i Taylor, Nigel. 2010. Children's Participation as a Struggle over Recognition. W: B. Percy-Smith, N. Thomas (red.), A Handbook of Children and Young People's Participation. Perspectives From Theory and Practice. New York: OXON, Routledge.

Hayward, Bronwyn. 2012. Children, Citizenship and Environment. London: Routledge. Holt, John. 1974. Escape from childhood: the needs and rights of childhood. New York: Dutton and Co inc.

Honeth, Axel. 2012. Walka o uznanie. Kraków: Nomos.

Jenks, Chris. 2008. Socjologiczne konstrukty dzieciństwa. W: M. J. Kehily (red.). Wprowadzenie do badań nad dzieciństwem. Kraków: Wydawnictwo WAM.

Johnson, Vicki. 2009. Children's Autonomous Organisation: Reflection from the Ground. W: Thomas N. ed., Children, politics and communication. Participation at the margins. Bristol: The Policy Press, University of Bristol.

Lansdowne, Gerison. 2010. Addressing the Balance of Power. W: M. Shuurman (red.). Valuing Children's Potentials. Brussels: Eurochild.

Lansdowne, Gerison G. 2019. Progress and challenges in child participation. W: M. Michalak (red.). Prawa dziecka wczoraj, dziś i jutro - perspektywa korczakowska. Warszawa: BRPD 
Liebel, Manfred. 2017. Adultyzm i dyskryminacja wobec dzieci ze względu na wiek. W: M. Liebel, U. Markowska-Manista. Prawa dziecka w kontekście wielokulturowości. Janusz Korczak na nowo odczytany. Warszawa: Wydawnictwo Akademii Pedagogiki Specjalnej.

Liebel, Manfred. 2017. Kulturowe wariacje form partycypacji dzieci. W: M. Liebel, U. Markowska-Manista, Prawa dziecka w kontekście międzykulturowości. Janusz Korczak na nowo odczytany. Warszawa: Wydawnictwo Naukowe Akademii Pedagogiki Specjalnej.

Lister, Ruth. 2009. Unpacking Children Citizenship. W: A. Invernizzi, J. Williams (eds.). Children and Citizenship. Los Angeles-Washington: SAGE.

Lundy, Laura. 2018. In defence of tokenism? Implementing children's right to participate in collective decision-making. "Childhood" 25(3): 340-354.

Lundy, Laura. 2007. Voice" is not enough: conceptualising article 12 of the United Nations Convention On The Rights Of The Child. "British Educational Research Journal" 33(6): 927-942.

Mannion, Greg. 2004. Beyond the Disneyesque: children's participation, spatiality and adult-child relations. "Childhood" 11(3): 303-318. https://doi. org/10.1177/0907568204044885

Mannion, Greg. 2010. After participation: The socio-spatial performance of intergenerational becoming. $W$ : B. Percy-Smith, N. Thomas (red.). A Handbook of Children and Young People's Participation. Perspectives From Theory and Practice. New York: OXON, Routledge.

O’Toole Therese i Gale, Richard. 2008. Learning from political sociology: structure, agency and inclusive governance. “International Journal of Children's Rights” 16(3): 369-378.

Percy-Smith, Barry. 1998. Children's Participation in Local Decision-Making. The Challenge for Local Governance. W: V. Johnson i in. eds., Stepping Forward: Children and Young People's Participation in the Development Process. London: It Publication.

Percy-Smith, Barry. 2010. Councils, consultation and community: Rethinking the space for children and young people’s participation. “Children's Geographies” 8(2): 107122.

Prawa dziecka. Dokumenty Organizacji Narodów Zjednoczonych. 2015. oprac. Paweł Jaros i Marek. Michalak, Biuro Rzecznika Praw Dziecka. Warszawa.

Prout, Alan i James, Allison. 1997. Introduction. W: Constructing and reconstructing Childhood. Contemporary Issues in the sociological study of childhood. London-Washington: Falmer Press.

Śliwerski, Bogusław. 2003. Współczesne teorie i nurty wychowania. Kraków: IMPULS.

Szczepska-Pustkowska, Maria. 2011. Od filozofii dzieciństwa do dziecięcej filozofii życia. Casus władzy (i demokracji). Kraków: IMPULS.

Taylor, Marilyn i Percy-Smith Barry. 2008. Children's Participation: Learning from and for Community Development. „International Journal of Children's Rights” 16(3): 379-394.

Thomas, Nigel. 2007. Towards a Theory of Children's Participation. „International Journal of Children's Rights” 15(2): 199-218. 
Thomas, Nigel. 2012. Love, Rights and Solidarity: Studying Children's Participation Using Honneth's Theory of Recognition. „Childhood” 19(4): 453- 466.

Tisdall, Kay. 2010, Governance and participation. W: Percy-Smith B., Thomas N. (eds.). A Handbook of Children and Young People's Participation. Perspectives From Theory and Practice. New York: OXON, Routledge.

Toots, Anu i Worley, Natalie i Skosireva, Anna. 2014. Children as Political Actors. W: G. Melton i in. (red.). The SAGE Handbook of Child Research. Los Angeles-Washington: SAGE.

Wyness, Michael. 2012. Childhood and Society. $2^{\text {nd }}$ ed. Basingstoke: Palgrave Macmillan. Wyness, Michael. 2018. Childhood, culture \& society. In a global context. Los Angeles: SAGE.

\section{Evolution of the discourse on social participation of children}

ABSTRACT: The concept of social participation of children is today understood multidimensionally, as an idea that is in fact polymorphous but also as an idea that is required to be implemented on different social levels. Since the clear expression of the idea placed in the Convention on the right of the child in 1989 its development in scientific discourse but also in practice one may be characterized as an evolution. The main change of it is perceiving today the participation more as a value and goal that should be reached rather than - as it was the past decades - as a tool and a method of developing the subjectivity of a child and democracy in a society. At the same time, it means that the discourse on children's participation has shifted towards the collective sense and is directed now to social and political theories which has become its theoretical background. The paper presents a draft describing this evolution.

KEYWORDS: children's participation, children's citizenship, rights of the child, democracy 
